\title{
Miejsce animacji kulturalnej w działalności polskich i rosyjskich lokalnych ośrodków kultury po przełomie ustrojowym (na wybranych przykładach)
}

$M$ odel upowszechnienia kultury stosowany w czasach komunistycznych i opierająca się na nim działalność kulturalno-oświatowa po przełomie ustrojowym przestały odpowiadać zapotrzebowaniu społecznemu w większości krajów Europy Środkowo-Wschodniej. Według wielu ekspertów, pojawiającym się w nowych warunkach zadaniom mogła częściowo sprostać animacja, która z jednej strony nastawiona jest na zaspokajanie potrzeb lokalnych, a z drugiej próbuje wykreować nowe wzory kulturowe, m.in. w procesie odtwarzania tożsamości regionalnej, lokalnej.

W niniejszym artykule chciałabym, opierając się na wybranych przykładach, zastanowić się nad tym, jakie zmiany nastąpiły w działalności lokalnych ośrodków kultury w Polce i w Rosji po przełomie ustrojowym i jakie miejsce zajmuje w tych zmianach animacja kulturalna'. Opierać się będę na badaniach empirycznych przeprowadzonych na potrzeby pracy doktorskiej obronionej w 2011 roku w Instytucie Socjologii Uniwersytetu Warszawskiego.

W czasie zmian ustrojowych zarówno w Polsce, jak i w Rosji istotne było pojawienie się nowych tendencji w rozwoju instytucji publicznych, do zadań których należy wsparcie inicjatyw mających na celu upowszechnianie kultury. Podkreślano znaczenie optymalizacji organizacji procesu kulturalnego oraz aktywny udział w nim potencjalnych odbiorców kultury. Jak pisze Bukraba-Rylska, to, „kto obecnie jest podmiotem życia kulturalnego w swoim środowisku, a kto ma świadomość braku wpływu i deprywacji potrzeb w tej dziedzinie, z kim osoby aktywne skłonne są nawiązywać współpracę oraz jakie reguły stosują w swoim postępowaniu, i wreszcie - z myślą o kim kształtowana jest lokalna oferta kulturalna, kto jest jej adresatem, stanowić będzie przyczynek do opisu «realnej demokracji». Ośrodki kultury stawały się więc bardziej uwrażliwione na zapotrzebowania

\footnotetext{
${ }^{1}$ W tekście używane są dwa pojęcia - animacji kulturalnej oraz animacji kultury. Animacja kulturalna to, według założenia autorki, metoda aktywizacji społecznej w różnych środowiskach. Termin animacja kultury odnosi się do działań związanych zwłaszcza z upowszechnieniem kultury i z edukacją kulturalną.
} 
kulturalne środowisk lokalnych. Warto zaznaczyć, że według opinii niektórych badaczy, społeczeństwa lokalne w swojej większości okazały się jednak niezupełnie przygotowane do udziału w rozwijaniu «demokracji kulturalnej»" [Bukraba-Rylska 2000: 45].

Z jednej strony, placówki kulturalne - zwłaszcza te o znaczeniu państwowym - mogły nadal liczyć na wsparcie finansowe ze środków publicznych, przyznawane im przez władze w postaci dotacji. Z drugiej strony, środków tych nie wystarczało na przeprowadzenie - koniecznej w nowej rzeczywistości - reformy działalności, m.in. na organizowanie niezbędnych szkoleń dla pracowników placówek kulturalnych czy zakup nowoczesnego sprzętu, umożliwiającego lepszy dostęp do społeczności lokalnej i kontakt z nią. Chcąc przetrwać w czasie reform gospodarczych, instytucje kultury zarówno w Polsce, jak i w Rosji musiały stanąć przed poważnym wyzwaniem: zostały zmuszone, by samodzielnie podjąć działania dotyczące opracowania nowych strategii marketingowych i menedżerskich. Większość placówek musiało dokonać zasadniczych zmian organizacyjnych, zwłaszcza w zakresie doszkalania swoich pracowników. Zadanie było niełatwe, ponieważ przed zmianami ustrojowymi pracownicy instytucji kultury byli nauczeni, że socjalizacja polega na rozpowszechnianiu i zakorzenianiu ideologii reżimu komunistycznego i na tym głównie opierała się ich działalność. Po przełomie ustrojowym znaczenia nabrały takie kompetencje pracowników kultury, jak umiejętność rozpoznania kulturalnych potrzeb środowiska, opracowywanie i realizowanie projektów społeczno-kulturalnych, planowanie i zdobywanie niezbędnych dla realizacji tych projektów środków finansowych, rozwijanie kapitału społecznego i kulturowego. Takie umiejętności mieli w krótkim czasie zdobyć pracownicy instytucji kultury, aby skutecznie działać w nowej rzeczywistości. Musiała się więc pojawić nowa formuła instytucji kultury, szczególnie na poziomie lokalnym: miały się one stać miejscem spotkań międzyludzkich i sprzyjać nawiązywaniu lepszych więzi interpersonalnych.

To, jakie placówki kulturalne się utrzymają, zależało często od tego, czy uda im się dostosować się do potrzeb mieszkańców danego regionu. Zdaniem Bohdana Skrzypczaka, w pierwszym okresie transformacji placówki kulturalne, zwłaszcza domy kultury, stosowały w większości „,proste recepty sprostania wyzwaniom polegające na szukaniu rezerw finansowych lub na koncentrowaniu się na działaniach przynoszących zysk, jak organizowanie dyskotek, koncertów, wypożyczalni wideo itd." [Skrzypczak 2003: 69]. Dopiero od 1992 roku zaczęły się pojawiać konsekwentne strategie zmiany funkcjonowania domów kultury. Samorządy zaczęły dostrzegać w placówkach kulturalnych istotne narzędzie polityki lokalnej, zaś ludzie, szczególnie miejscowi liderzy, poczuli, że potrzebne im są miejsca spotkań. Właśnie w tym czasie - jak zaznacza Bohdan Skrzypczak - zaczęto dostrzegać „,potrzebę kulturalno-oświatowej interwencji w środowiskach zagrożonych 
Artykuły

marginalizacją" [Skrzypczak 2003: 70]. W wielu gminach zaczęto więc odbudowywać zlikwidowane po przełomie ustrojowym świetlice wiejskie. I chociaż na początku transformacji zlikwidowano dwa razy więcej domów i ośrodków kultury niż utworzono nowych [Gajewska 1992: 82] i zlikwidowano ponad trzy razy więcej niż utworzono klubów i świetlic, to instytucje kultury, które się utrzymały, nauczyły się dostosowywać do nowych realiów. Bohdan Skrzypczak podkreśla, że szczególne znaczenie nadawał tym zmianom fakt, iż na początku lat 90. „stopniowo wzrasta świadomość i potrzeba ponownego integrowania środowiska" [Skrzypczak 2003: 76]. W wyniku zasadniczych zmian politycznych i trudności finansowych większość Polaków utraciło bowiem poczucie bezpieczeństwa, starało się też oswoić z warunkami gospodarki rynkowej, co w oczywisty sposób odciągało ich od spraw kultury.

Jako skuteczna forma działania w dziedzinie kultury w Polsce zaczęła się sprawdzać animacja kultury. Praktyka pokazywała, że może ona być remedium nie tylko na problemy w dziedzinie kultury, ale i w innych sferach życia społecznego. Według Jana Grada i Urszuli Kaczmarek konieczne stało się m.in. opracowanie „obiektywnego inwentarza metod i propozycji związanych z animacją niedyrektywną i samorządnością", zbadanie i opracowanie technik ,„przydatnych animatorom zbiorowości lokalnych do zachęty członków tych zbiorowości do uczestnictwa społeczno-kulturalnego", rozwiązanie problemu grup społecznych zepchniętych na margines, przeanalizowanie warunków owocnej współpracy władz, animatorów i przedsiębiorców, zacieśnianie więzi między animacją a wychowaniem [Grad, Kaczmarek 2005:127]. Zaletą animacji jest niewątpliwie to, że jej głównym celem nie jest nauczanie o kulturze i promowanie pewnych wzorów, lecz zachęcanie odbiorców do samodzielnego udziału w procesie ich tworzenia. Zdaniem Jana Grada i Urszuli Kaczmarek, animacja implikuje szereg ważnych procesów powiązanych między sobą: stworzenie odpowiednich warunków, w których grupa i jednostka będą chciały powiedzieć o swoich problemach i potrzebach, ujawnienie związków między sobą a środowiskiem oraz „kreację wyrażającą się poprzez samokreację, działania twórcze jednostki, grupy zintegrowanej z otoczeniem" [Grad, Kaczmarek 2005: 127].

Właśnie animacja kultury jako główna metoda integracji jest obecna na przykład w strategii działania Centrum Spotkań Europejskich „Światowid” w Elblągu. Realizowany jest tam projekt „Akademia Pana Kleksa” przeznaczony dla dzieci z rodzin zastępczych. Opiera się na ciekawie zorganizowanych warsztatach z różnych dziedzin kultury i sztuki dla dzieci i młodzieży. Wyznaczyliśmy dla siebie kilka ważnych zadań - opowiada dyrektor Centrum Antoni Czyżyk. - Po pierwsze, integracja, której sprzyjały gry i zabawa jako forma tych spotkań. Po drugie, chcieliśmy nauczyć dzieci podstawowych zasad współpracy w grupie. Od razu ustaliliśmy zasady Akademii: 
- Akademia wszystko robi razem,

- Akademia słucha swoich opiekunów,

- Akademia dba o swój totem².

Na szczególne podkreślenie zasługuje działalność Centrum „Światowid” na rzecz osób niepełnosprawnych. Ośrodek uważany jest za placówkę przodującą w województwie warmińsko-mazurskim w działaniach z zakresu artterapii osób niepełnosprawnych. Systematycznie prowadzone są tam warsztaty artystyczne (ceramiczne, muzyczne, teatralne i plastyczne), przeglądy i konkursy, m.in. Regionalne Prezentacje Artystyczne Specjalnych Ośrodków Szkolno-Wychowawczych, Ogólnopolskie Spotkania Artystyczne Osób Niepełnosprawnych oraz Spotkania Artystyczne Osób Niepełnosprawnych „Euroregionu Bałtyk” i „,Razem w Euroregionie”. Postanowiliśmy, że nie będziemy już więcej podkreślać niepełnosprawności. Organizujemy przedsięwzięcia, które mają pokazać, że wszyscy żyjemy na jednej planecie i nie powinno robić się jakichkolwiek rozróżnień ${ }^{3}$ - zaznacza Teresa Miłoszewska, koordynatorka projektów adresowanych do osób niepełnosprawnych. W 2010 roku takim projektem stał się konkurs literacki dla niewidomej młodzieży pod hasłem „Cudowne lata”. Prace nagrodzone w konkursie zostały opublikowane, a ich autorzy wezmą udział w następnych warsztatach teatralnych, muzycznych oraz zajęciach z emisji głosu. Efektem prowadzonych przez specjalistów warsztatów będzie stworzenie słuchowiska radiowego na podstawie popularnej powieści młodzieżowej. Warto zaznaczyć, że projekty te są otwarte dla szerokiej publiczności i cieszą się znacznym prestiżem.

Jeszcze jedną ciekawą inicjatywą ośrodka „Światowid” było zorganizowanie w 2009 roku cyklu szkoleń „Akademia Animatora Wiejskiego” dla animatorów działań lokalnych. Głównym celem tego projektu było pomnożenie wiedzy i umiejętności czternastu animatorów z lokalnych wsi - młodzieży oraz osób dorosłych, którzy pragną aktywizować własne środowisko wiejskie, rozwijać je i zmieniać. Chcieliśmy, z jednej strony, wykorzystać potencjał ludzi mieszkających na terenach wiejskich do poprawy jakości życia środowiska wiejskiego, a z drugiej, ożywić życie kulturalne na terenie Warmii i Mazur ${ }^{4}$ - zaznacza dyrektor Centrum Antoni Czyżyk.

Dobrym przykładem organizacji pozarządowej, która stosuje animację kulturalną jako metodę skutecznego oddziaływania na środowisko lokalne, jest Stowarzyszenie „Tratwa” z Olsztyna. Prezes Stowarzyszenia Ryszard Michalski mówi o tym tak: Określiliśmy od samego początku swoją misję jako stworzenie przestrzeni, w której mogłyby spotkać się spychane na margines swoiste „mniejszości kulturowe”. Z jednej strony, mieliśmy do czynienia

${ }^{2}$ Wywiad z Antonim Czyżykiem, Elbląg, 2009.

${ }^{3}$ Wywiad z Teresą Miłoszewską, Elbląg, 2009.

${ }^{4}$ Tamże. 
Artykuły

z przedstawicielami zanikającej polskiej kultury tradycyjnej (jak na przykład śpiewaków z Kurpiów), a z drugiej widzieliśmy problemy, z którymi borykają się przesiedleńcy z ukraińskich wiosek na Warmii. Nie mogliśmy pominąć również ludzi młodych - twórców i animatorów spontanicznych kultur młodzieżowych, pragnących coś robić i zazwyczaj odrzucanych przez formalne struktury ${ }^{5}$. Dlatego wśród pierwszych projektów tego stowarzyszenia były działania mające doprowadzić do stworzenia środowiska animatorów, bez których, według Michalskiego, niemożliwa jest „,kultura wymiany”. Na przykład projekty: „Archipelag”, którego celem było organizowanie i wspieranie ogólnopolskiej sieci ośrodków pracujących z młodzieżą oraz „Centra aktywności młodych” - prowadzenie systematycznej pracy animacyjnej aktywizującej środowiska młodzieżowe oraz tworzenie centrów wolontariatu.

W wieloletnim projekcie „Ogniwa” została z kolei zrealizowana druga strategia stowarzyszenia. Ryszard Michalski opowiada: Upewniliśmy się w praktyce, że elementem dynamizującym rozwój społeczności lokalnych może być zróżnicowanie kulturowe i etniczne. Podstawowym założeniem naszego przedsięwzięcia było przekonanie, że specyficzna dla naszego regionu sytuacja: społeczeństwo wielokulturowe zamieszkujące Warmię, ziemia nieposiadająca własnej tradycji czy kultury, zamieszkana jednak przez bogatą w przeszłość społeczność, która nigdy nie używała swojej kultury i nie mogła manifestować swojej odmienności, może stać się medium komunikacji ze społecznością dorosłych i „światem instytucji”. Zaczęliśmy zbierać opowieści i gromadzić ludzi, żeby oni sobie nawzajem te historie opowiadali i było to coś niesłychanego. W większości wypadków to były historie opowiadane pierwszy raz nie tylko sąsiadom, ale i najbliższym, dzieciom, wnukom. Dzięki temu projektowi zrozumieliśmy, że wieś nie istnieje bez zgromadzeń, że istotą społeczności jest to, że ludzie się gromadzą?.

W ramach tego projektu pracownicy stowarzyszenia „Tratwa”, nagrywając wspomnienia najstarszych mieszkańców Olsztyna, starali się docierać do pamięci kulturowej tych terenów. W ten sposób została stworzona strona wirtualnych muzeów ${ }^{8}$ oraz wydano zbiór opowieści mieszkańców „Księga Ogniw”. Od roku 2007 stowarzyszenie zaczęło kierować swoje działania do wiejskich liderek, zakładając, że poprzez odbudowę kapitału kulturowego wzmocni się kapitał społeczny tych terenów. Rezultatem był projekt „Wzmacnianie społeczno-obywatelskich umiejętności kobiet w wioskach wielokulturowych w północno-wschodniej Polsce" (2008-2010), finansowany ze środków Trust for Civil Society in Central \& Eastern Europe.

\footnotetext{
${ }^{5}$ Wywiad z Ryszardem Michalskim, Ełk, 2008.

${ }^{6}$ Tamże.

7 Tamże.

8 http://ogniwa-tratwa.pl/.
} 
Jak wynika z analizy wywiadów przeprowadzonych wśród uczestników projektu „Ogniwa”, jego działania zbliżyły do siebie ludzi, umożliwiły im lepsze poznanie się i spowodowały, że zaczęli się ze sobą częściej spotykać. Na tej podstawie można stwierdzić, że projekt, który zaczął się od zbierania ciekawych opowiadań okolicznych mieszkańców, zainicjował proces reintegracji społecznej.

Nie ulega wątpliwości, że wyżej wymienione procesy wymagają od osób, które je inicjują, odpowiednich umiejętności, a co najważniejsze, innego sposobu myślenia niż ten, który występował za czasów komunistycznych. Bierne przekazywanie informacji zmieniło się w nowym modelu kultury w ,,pobudzanie i rozwijanie zdolności, jednostkowego rozumienia zjawisk, procesów, ludzi" [Dyczewski 1993: 203]. Oznacza to jednocześnie, że narodził się nowy typ pracownika kultury, animator w prawdziwym znaczeniu tego słowa, o którym trafnie napisał Leon Dyczewski: ,to osoba, która dopełnia wiedzę, doświadczenia życiowe oraz przeżycia ludzi, rozbudza ich zainteresowania, ukazuje nowe ideały i wzory życia, prowadzi z nimi dialog nad możliwościami i sposobami rozsądnego zaspokajania ujawnionych i jeszcze ukrytych potrzeb kulturalnych" [Dyczewski 1993: 203].

Po przełomie ustrojowym w Polsce zostały podjęte konstruktywne inicjatywy na polu edukacji kadry domów kultury. Wprowadzono nowe kierunki kształcenia i dokształcania animatorów i menedżerów kultury na studiach uniwersyteckich, zaproponowano także różne formy edukacji pozauczelnianej. Istotny wkład w przygotowanie nowoczesnych animatorów kultury wniosły takie ośrodki, jak Centrum Animacji Kultury, Centrum Wspierania Aktywności Lokalnej w Warszawie i wiele innych.

Ciekawe, że o ważnym znaczeniu animacji jako działalności pobudzającej zaangażowanie odbiorców kultury, rosyjscy kulturoznawcy i socjolodzy kultury również zaczęli pisać na początku lat 90. (za czasów pieriestrojki). W zbiorze artykułów naukowych wydanych przez Ministerstwo Kultury Akademii Nauk ZSRR pod tytułem „Perspektywiczne modele instytucji kultury” zaznaczono, że pracownik kultury, zgodnie z wymogami dokonujących się przemian społecznych, powinien występować w roli badacza i moderatora nowych metod pracy z odbiorcami, a jego głównym zadaniem jest stworzenie najkorzystniejszych warunków dla twórczości i rozwoju osobowego. Ważne jest, żeby - jak piszą Siergiej Ewremow i Evgenii Kunin - „stworzyć w każdym ośrodku kultury atmosferę twórczych poszukiwań, gry, zabawy, eksperymentu. Należy przy tym nie bać się przekraczania ograniczeń biurokratycznych i wprowadzać konsekwentne zmiany do organizacji pracy instytucji kultury w celu ich demokratyzacji i skuteczności" [Ewremow, Kunin 1990: 34]. Jako udany przykład autorzy podają dom kultury w miejscowości Puszkino, który przeszedł ewolucję od zwyczajnego lokalnego ośrodka, w którym działało kilka kół amatorskich, niecieszących się jednak zbyt dużą popularnością, do centrum życia kulturalno- 
Artykuły

-społecznego. Ewolucja ta okazała się możliwa dzięki zasadniczej zmianie form pracy tego ośrodka. Oferty kulturalne domu kultury zostały opracowane w taki sposób, żeby zmusić mieszkańców miejscowości, by przestali być biernymi obserwatorami, stając się czynnymi uczestnikami i twórcami. Sprzyjał temu, na przykład, specjalnie powołany teatr komunikacji „,Fanta”. Spektakle tego teatru polegały na opowiadaniu sobie nawzajem historii z życia wziętych na wybrany wcześniej wspólnie temat. Dużą popularnością zaczął się cieszyć również program „Dżem-show”, który składał się z koncertów, dyskotek dla młodzieży oraz dyskusji i rozmaitych gier intelektualnych. Nowatorstwo tego programu polegało na tym, że wymyślali i organizowali go sami mieszkańcy, a pracownicy domu kultury służyli im wyłącznie pomocą.

Jednak po upadku ZSRR ta forma działalności instytucji kultury, zwłaszcza na poziomie lokalnym, nie zyskała popularności. W trudnych warunkach transformacji nie było miejsca na eksperymenty i poszukiwanie nowych koncepcji działania instytucji kultury. Choć niektóre domy kultury próbowały stosować w swojej działalności animację kulturalną, dotyczyło to tylko dużych miejscowości, jak Moskwa i Petersburg.

Można stwierdzić, że wprowadzanie animacji kulturalnej w Rosji drugiej połowy lat 90. załamało się z powodu ostrego kryzysu finansowego. Przyczynił się do tego również brak odpowiednich warunków do wprowadzania tych praktyk w życie. Warto też zwrócić uwagę, że w Rosji problematyka rozwoju kultury na płaszczyźnie lokalnej rozpatrywana była inaczej niż w Polsce. Na poziomie organizacyjnym polskie lokalne ośrodki kultury miały większą samodzielność niż rosyjskie, co powodował przede wszystkim „,czynnik ludzki”: w Rosji przyzwyczajeni do kontroli przedstawiciele władzy miejscowej oraz kierownicy placówek kulturalnych starali się konsultować wszystkie swoje pomysły z centrum. W porównaniu z polskimi, rosyjskie lokalne ośrodki kultury były w gorszej sytuacji zarówno pod względem infrastruktury, jak i kadr. Poza tym w systemie kształcenia państwowego nie pojawiła się specjalizacja animatora kultury. Na niektórych uczelniach powstały propozycje kursów dla organizatorów kultury, ale ich program jedynie w niewielkim stopniu uwzględniał doświadczenie instytucji zachodnich w kształtowaniu oferty kulturalnej. Dopiero w drugiej połowie lat 90. zwrócono uwagę na konieczność przygotowania pracowników w zakresie managementu, marketingu, animacji oraz finansowania kultury. Nie sposób nie zauważyć również wolniejszej niż w Polsce modernizacji rosyjskich instytucji, szczególnie lokalnych domów kultury i muzeów. Większość ośrodków kultury w małych rosyjskich miejscowościach nadal nie ma stałego łącza internetowego i własnej strony internetowej. Różnica widoczna jest także w organizacji finansowania kultury. W Rosji sponsoring prywatny dopiero nabiera znaczenia. Oligarchowie rosyjscy zaczęli powoływać fundacje, których celem jest wspieranie inicjatyw kulturalnych. Można 
więc przypuszczać, że po przełomie ustrojowym lokalne ośrodki kultury kierowały się w swojej działalności w większości starymi schematami, a największą wagę przywiązywały do tego, jak utrzymać się za małe pieniądze pochodzące z budżetu państwowego. Na poziomie lokalnym kierownictwo większości instytucji kultury oczekiwało wsparcia finansowego ze strony państwa i uzależniało swoją działalność od środków uzyskanych z budżetu samorządowego.

Na przełomie 2002/2003 roku w sferze kultury w Rosji zaczęły zachodzić zmiany spowodowane m.in. poprawą stanu gospodarki i osiągnięciem stabilności w różnych dziedzinach życia społecznego. Pracownicy instytucji kulturalnych oraz działacze trzeciego sektora zwrócili uwagę na skuteczność metod animacji kulturalnej w rozwiązywaniu wielu problemów społecznych. Chodzi na przykład o zahamowanie rozprzestrzeniania się alkoholizmu i narkomanii wśród młodzieży, łagodzenie nacjonalistycznych tendencji w pewnych środowiskach, pokonanie bierności mieszkańców małych miejscowości i wiosek. Praktyka pokazywała, że metody stosowane w animacji kulturalnej pobudzają aktywność lokalną i sprzyjały rozwojowi inicjatyw obywatelskich.

Jednocześnie coraz większą popularność zaczęło zdobywać pojęcie menedżera kultury jako osoby odpowiedzialnej za organizację całego procesu kulturalnego - od założeń merytorycznych, poprzez zdobycie środków finansowych, do ewaluacji. Specjalizację tę wprowadzono do programu niektórych uczelni, w większości o profilu ekonomicznym.

Ciekawym przykładem jest Asociacia menedżerow kultury (Stowarzyszenie Menedżerów Kultury), która została powołana w 2003 roku jako ogólnorosyjska pozarządowa organizacja sieciowa. Łączy ona kulturoznawców, socjologów, menedżerów kultury, muzeologów i pracowników ośrodków kulturalnych. Udało się jej zrealizować kilka dużych projektów, spośród których warto wymienić: projekt badawczy „Kultura dla Baleia” w ramach programu „W kierunku społeczeństwa obywatelskiego”, roczny cykl seminariów „Management w dziedzinie etnokultury: kompetencje, innowacje, systemy nauczania” oraz projekt internetowy „AmKarta”. Ten ostatni projekt miał na celu stworzenie bazy danych gromadzącej informacje o menedżerach kultury, skutecznie działających instytucjach oraz efektywnych projektach regionalnych o charakterze społeczno-kulturalnym. Zadaniem projektu było także gromadzenie informacji na temat badań prowadzonych w dziedzinie upowszechniania kultury.

Jednym z głośnych projektów, w których bierze udział Stowarzyszenie Menedżerów Kultury, jest konkurs „Zmieniające się muzeum w zmieniającym się świecie”9 , którego celem jest wspieranie innowacyjnego podejścia do działalności muzealnej oraz dostoso-

\footnotetext{
${ }^{9}$ Oryginalny rosyjski tytuł konkursu: Mieniajusziisea muzej w meniaiuszemsea mire.
} 
Artykuły

wanie się muzeów do nowych warunków ekonomicznych, społecznych i kulturowych. Zapoczątkowany w 2003 roku, jest obecnie jednym z największych corocznych wydarzeń kulturalnych. W konkursie tym biorą udział muzea państwowe i prywatne, a także inne instytucje kultury i organizacje pozarządowe. Uczestnicy konkursu mogą otrzymać grant na realizację swoich projektów, dzięki czemu ich instytucja może stać się centrum życia kulturalnego i społecznego środowiska lokalnego. Głównym organizatorem i sponsorem tego konkursu jest Fundacja Dobroczynna rosyjskiego oligarchy Władimira Potanina; wsparcie merytoryczne zapewnia Ministerstwo Kultury Federacji Rosyjskiej, a koordynatorem jest wyżej wymienione Stowarzyszenie Menedżerów Kultury. Organizatorzy tego konkursu postawili przed sobą niewątpliwie niełatwe zadanie - przekształcić muzea w miejsca atrakcyjne dla szerokiej publiczności. Projekt ten był szeroko prezentowany w środkach masowego przekazu - zarówno rosyjskich, jak i zagranicznych. Pod jego wpływem, w wyniku współpracy pracowników muzeów i mieszkańców, powstało wiele inicjatyw muzealnych, które urozmaiciły lokalną ofertę kulturalną.

Jak twierdzi Anastasja Makarenko, członkini Stowarzyszenia Menedżerów Kultury, obecnie w Rosji, szczególnie na prowincji, centrami integracyjnymi społeczności lokalnych stają się często właśnie muzea, ponieważ posiadają bogate zasoby, do których należą zarówno zbiory i kolekcje, jak i potencjał ludzki. Są też cennym źródłem wiedzy historycznej, która jest niezbędna dla przywrócenia tożsamości narodowej zniszczonej w czasach radzieckich ${ }^{10}$. Jeden z najbardziej znanych rosyjskich badaczy w dziedzinie muzeologii, Władimir Dukielsky, za główną rolę muzeów w Rosji uważa właśnie „pomoc w odrodzeniu zapomnianych tradycji i wypełnienie luki w zapotrzebowaniach społecznych" [Koweshnikowa 2008: 25].

Warto zwrócić uwagę na projekty przeprowadzone przez stowarzyszenie w latach 2009 i 2010. W tych projektach jedną z głównych metod pracy z odbiorcami jest właśnie animacja kulturalna. Latem 2009 roku w wiosce Nikoła-Leniwiec w obwodzie kałużskim zorganizowano festiwal „Archstojanie-2009”, którego celem było opracowanie koncepcji muzeum pod otwartym niebem wzorowanych na najlepszych europejskich i rosyjskich doświadczeniach i innowacyjnych technologiach. Jednym z ważniejszych zadań tego projektu było stworzenie edukacyjnej platformy interaktywnej, opierającej się na systematycznych warsztatach, seminariach, dyskusjach okrągłego stołu oraz rozmowach na aktualne tematy dotyczące rozwoju wioski i w perspektywie - całego obwodu kałużskiego. Należy podkreślić, że w tych dyskusjach, według założeń projektu, brali aktywny udział przedstawiciele miejscowej społeczności.

\footnotetext{
${ }^{10}$ Anastazja Makarenko, strona internetowa Stowarzyszenia Menedżerów Kultury, http://www.amcult.ru/.
} 
Ważnym przykładem działalności mającej na celu rozwiązanie problemów społecznych za pomocą kultury jest również projekt „Twórcze Południe. Kulturalno-symboliczne zasoby południa Federacji Rosyjskiej”, który Stowarzyszenie Menedżerów Kultury zaczęło realizować w 2010 roku przy finansowym wsparciu funduszu zachodniego - OSI Assistance Foundation. Projekt ten przewiduje nawiązanie współpracy instytucji państwowych i organizacji pozarządowych w celu realizacji socjalnych i kulturalnych przedsięwzięć wspierających rozwój południowych regionów Federacji Rosyjskiej. Skomplikowana sytuacja na Kaukazie powoduje w tych regionach zakłócenia w komunikacji i wymianie doświadczeń między poszczególnymi miejscowościami i instytucjami, szczególnie w dziedzinie kultury. Z powodu nieustannych konfliktów rzadko organizuje się na tym obszarze duże imprezy kulturalne. Wyraźnie brakuje przedsięwzięć mających na celu zjednoczenie poszczególnych terenów tego regionu w jednolitą przestrzeń kulturalną. Powodem tego jest również brak oddolnej chęci współpracy między przedstawicielami różnych narodów. Zgodnie z założeniami Stowarzyszenia Menedżerów Kultury, projekty w dziedzinie animacji kulturalnej mogą stworzyć odpowiednie warunki, by zjednoczyć siły artystów, muzyków, przedsiębiorców oraz pracowników instytucji kulturalnych i trzeciego sektora, i w ten sposób wzmocnić lokalne środowisko. Ważne jest dla tych terenów także zdobycie doświadczenia w dziedzinie zarządzania kulturą i współczesnych efektywnych metod pracy, w tym właśnie animacji kulturalnej.

Przykład Stowarzyszenia Menedżerów Kultury świadczy o tym, że w środowisku rosyjskich specjalistów $w$ dziedzinie kultury istnieje silna potrzeba rozwijania warsztatu, aby móc sprostać współczesnym wyzwaniom. Pokazuje też, że państwo nie jest już monopolistą w tej sferze, że nawet nieliczna grupa entuzjastów może założyć własną organizację i zapełnić jakąś lukę w rozwoju i kształtowaniu nowych metod pracy instytucji kultury.

Nie mniej ciekawym przykładem skutecznej działalności w zakresie animacji społeczno-kulturalnej jest Park Ptaków, który został założony przez małżeństwo moskiewskich ornitologów w 2007 roku w małej wiosce Wróble na granicy obwodów moskiewskiego i kałużskiego ${ }^{11}$. Park Ptaków ma status organizacji pozarządowej. Jest to pierwszy w Rosji park utworzony na wzór strefy rekreacyjnej przeznaczonej do wypoczynku rodzinnego. Ekspozycja parkowa liczy ponad 200 gatunków ptaków, wśród których są nie tylko takie, które można spotkać w Rosji, ale również pochodzące z egzotycznych zakątków świata. Park obejmuje 12 hektarów i oprócz ekspozycji ptaków znajdują się w nim place zabaw dla dzieci, tarasy, które można wykorzystywać jako miejsce na piknik lub spotkanie. Należy zaznaczyć, że w ostatnich latach (2009-2012) zaczęto tu organizować coraz więcej dyskusji

${ }^{11}$ W Rossii otkryli park ptic, „Wiadomości Kaługi”, 22.07.2004, www.gnuman.ru/travel/voroby. 
Artykuły

publicznych na aktualne tematy, dotyczące życia mieszkańców obwodów moskiewskiego i kałużskiego. Podczas tych spotkań omawiane są również ciekawe wydarzenia kulturalne $w$ tym regionie. Warto zwrócić uwagę na to, że powstanie tego parku stworzyło wiele nowych miejsc pracy dla mieszkańców wioski Wróble, ożywiło to miejsce, uczyniło je atrakcyjnym dla turystów. Obecnie park jest jednym z częściej odwiedzanych w weekendy miejsc w obwodach moskiewskim i kałużskim. W wyniku tego projektu - jak zaznacza jeden z jego założycieli, Aleksander Bielawski - mieszkańcy wioski Wróble zaczęli przejawiać aktywność, o czym może świadczyć ich zaangażowanie w rozmaite imprezy kulturalne zorganizowane w Parku Ptaków ${ }^{12}$.

Jeszcze raz chciałabym zaznaczyć, że nie jest to przedsięwzięcie państwowe, lecz inicjatywa małej grupy ludzi. Ten przykład wyraźnie pokazuje, że istnieje duże zapotrzebowanie na tego rodzaju inicjatywy, dzięki którym ludzie odczuwają, że mają wpływ na jakość swojego życia. W warunkach rosyjskich, gdzie w wielu wioskach są opuszczone sowchozy, ponieważ nie ma pomysłów i środków finansowych na ich zagospodarowanie, taka działalność nabiera dodatkowego znaczenia. Świadczy także o tym, że w Rosji w środowisku animatorów kultury oraz ekspertów zaczyna się pojawiać nowa wizja kultury. Sprawy polityczne po przełomie ustrojowym zbyt długo znajdowały się w centrum uwagi społeczeństwa rosyjskiego, zaś rola kultury oraz inicjatyw pozarządowych była mocno marginalizowana. Trzeba jednak zaznaczyć, że w Federacji Rosyjskiej animacja kulturalna jest nadal częściej stosowana w działalności organizacji pozarządowych niż instytucji państwowych. W małych miejscowościach zamiast określenia ,„animator kultury” jest używane pojęcie massowika-zatejnika ${ }^{13}$ jako osoby, która organizuje i prowadzi masowe imprezy kulturalne i często występuje w roli „łącznika” między instytucją kultury a odbiorcami. Ośrodki kultury w Rosji, korzystając de facto z animacji kulturalnej, wolą nazywać tę metodę po prostu ,nowym podejściem do odbiorców” [Kisilewa, Krasilnikow 2004: 24].

Na przykład Dom Twórczości Narodowej w Tule stosuje metody, które z całą pewnością można odnieść do współczesnych metod animacji kulturalnej, ale łączy je ze starymi oswojonymi praktykami. Koordynowane przez ten ośrodek kółka amatorskie - jako podstawowa forma organizacji życia kulturalnego na wsi - coraz bardziej przypominają centra aktywności lokalnej. Ośrodek proponuje mieszkańcom samodzielne opracowywanie planu imprez kulturalnych i ich organizację, biorąc na siebie uzyskanie środków finansowych - z budżetu lokalnego lub państwowych programów grantowych. Udział pracowników Domu Twórczości Narodowej ogranicza się wówczas do roli opiekunów merytorycznych.

\footnotetext{
12 Tamże.

${ }^{13}$ Tzw. organizatora kultury (określenie z czasów ZSRR).
} 
Jak twierdzi dyrektor tego ośrodka Wadim Barysznikow, podobna strategia sprzyja wzrostowi aktywności mieszkańców, odciąga młodzież od bardzo rozpowszechnionego na wsi nałogu, jakim jest alkoholizm. Właśnie dzięki inicjatywie grupy młodych ludzi w jednej z małych wiosek zaczęto obchodzić Święta Pokrzywy, co przyniosło tej miejscowości nie tylko popularność, ale i realne możliwości zwiększenia dochodów. W ramach tego festiwalu organizowane są konkursy i jarmarki, warsztaty rękodzieła oraz koncerty. Daje to olbrzymi impuls do rozwoju wyobraźni i twórczości mieszkańców, którzy w taki sposób maja możliwość zaprezentować siebie na nowo w swoim środowisku ${ }^{14}$ - podkreśla w rozmowie dyrektor Domu Twórczości Narodowej.

Analiza przeprowadzonych przeze mnie wywiadów z pracownikami Domu i kwestionariuszy zebranych wśród mieszkańców pozwala stwierdzić, że ośrodek ten, wykorzystując w praktyce koncepcję animacji kulturalnej, inicjuje wiele wydarzeń kulturalnych oraz motywuje i zachęca do uczestnictwa w nich przedstawicieli lokalnych społeczności. Do najbardziej udanych należy międzyregionalny festiwal folkloru „Dwanaście źródeł”, międzyregionalna wystawa wiejskich artystów „Polana artystów” oraz regionalny festiwal twórczości dzieci z ograniczonymi możliwościami.

Szczególną formą działania Domu Twórczości jest udzielanie porad i udostępnianie materiałów informacyjnych organizatorom wiejskich klubów obwodu tulskiego. Na prośbę wiejskich działaczy kultury specjaliści ośrodka odwiedzają kluby, niosąc pomoc zarówno metodyczną, jak i praktyczną, na przykład angażując się w przygotowania do miejscowych przedsięwzięć. Organizują też - w zależności od potrzeb wiejskich działaczy - warsztaty i szkolenia, w których mogą wziąć udział przedstawiciele lokalnej społeczności. W 2006 roku, na przykład, największą popularnością cieszyła się „,Szkoła rosyjskiego folkloru”; uczestnicy tych spotkań mogli nie tylko dowiedzieć się, jak rozwijała się tradycyjna kultura pieśni i jak zmieniał się strój narodowy w obwodzie tulskim, ale i sprawdzić swoje umiejętności - na przykład wokalne. Jak zaznacza Wadim Barysznikow, w ostatnich latach w takich przedsięwzięciach brali udział ludzie młodzi ${ }^{15}$. Warto dodać, że ze względu na specyfikę tej instytucji nie wszyscy jej pracownicy mają wyższe wykształcenie. Jak podkreślił w rozmowie dyrektor tego ośrodka Wadim Barysznikow, żeby być dobrym organizatorem życia kulturalnego na wsi, przede wszystkim trzeba mieć doświadczenie, wiedzę o tradycjach lokalnych, kreatywność oraz umiejętność dogadywania się z ludźmi. ${ }^{16}$

W planach Domu Twórczości Narodowej jest powołanie centrum twórczości dziecięcej oraz centrum folkloru obwodu tulskiego. W opinii dyrektora ośrodka to właśnie

\footnotetext{
${ }^{14}$ Wywiad z Wadimem Barysznikowem, Tuła, 2010.

15 Tamże.

${ }^{16}$ Tamże.
} 
Artykuły

lokalne tradycje mogą odgrywać w wiejskiej społeczności rolę integracyjną, poza tym, dzięki umiejętnej promocji tych tradycji obwód tulski może zyskać w sensie ekonomicznym oraz wzmocnić swój wizerunek na poziomie krajowym. ${ }^{17}$ Podsumowując, liczba prowadzonych przez Dom Twórczości Narodowej przedsięwzięć i ich wszechstronność świadczą o tym, że jest to instytucja kulturalna nowego typu, która dąży do tego, by być zauważoną przez środowiska lokalne, a stosując własną strategię, reaguje również na kulturalne, i inne, potrzeby mieszkańców obwodu Tulskiego.

Zastanawiając się nad rolą animacji kulturalnej w działalności lokalnych ośrodków kultury w Polsce i Rosji, można dojść do następujących konkluzji:

- ponieważ polityka kulturalna po przełomie ustrojowym w Rosji w porównaniu z Polska była bardziej „,scentralizowana”, rosyjskie instytucje kultury rzadziej stosowały animacje kulturalną niż instytucje polskie,

- w Polsce zarówno badacze, jak i pracownicy ośrodków kultury coraz chętniej i częściej używają pojęcia animacji kulturalnej. W Rosji zamiast tego stosuje się pojęcie organizacji procesu kulturalnego; ośrodki kultury o statusie stowarzyszeń pozarządowych, naśladujące wzorce zachodnie, preferują określenie: management kultury,

- jak trafnie zauważa Bohdan Skrzypczak, w okresie transformacji w Polsce rozkwitła forma uczestnictwa w kulturze określana jako kultura czynna, która istniała też za czasów PRL-u, ale znajdowała się na marginesie scentralizowanego państwowego systemu upowszechnienia kultury [Skrzypczak 2003: 68],

- jak pokazują badania takie jak studium „Nierówności w kulturze Polaków i Rosjan”, przeprowadzone przez Instytut Kultury w Warszawie ${ }^{18}$, na samym początku transformacji Rosjanie byli bardzo otwarci na kulturę i przywiązywali dużą wagę do uczestnictwa w kulturze. Zmieniło się to gwałtownie po kryzysie konstytucyjnym i gospodarczym 1993 roku. Większość Rosjan w połowie lat 90. cechuje pasywność i pesymistyczny stosunek do otaczającej rzeczywistości. Jak zaznacza Viktor Tarnavskyi [Tarnavskyi 2007:45], do tych nastrojów społecznych przyczynił się również fakt, że w miejsce radzieckich organizacji społecznych nie powstały nowe organizacje, stanowiące podstawę społeczeństwa obywatelskiego,

- w okresie transformacji w Polsce organizacje pozarządowe w pewnym sensie uzupełniały działalność placówek kulturalnych, m.in. w tworzeniu szans aktywnego uczestnictwa w kulturze dla zwykłych odbiorców. W Rosji rozwój trzeciego sektora nastąpił znacznie później i nie odgrywał tak znaczącej roli w przemianach społecznych, jak w Polsce.

\footnotetext{
17 Tamże.

${ }^{18}$ Koncepcja projektu została opisana w książce Nierówności w kulturze Polaków i Rosjan [Gawda 1991].
} 
Sytuacja jednak zaczęła się zmieniać w ciągu ostatniej dekady: analiza poszczególnych inicjatyw kulturalnych wskazuje na to, że mają one nieduży, ale zauważalny wpływ na uczestnictwo w kulturze zwykłych ludzi oraz na pobudzanie ich do zaangażowania się w życie społeczności,

- w Polsce działalność organizacji pozarządowych funkcjonujących w dziedzinie kultury często opiera się na wartościach umożliwiających spajanie społeczeństwa i tworzenie wspólnoty. Stanowiq̨ one swoistego rodzaju pomost między społeczeństwem a władzq̨ oraz między przedstawicielami różnych środowisk, pomagając $w$ ten sposób w rozwiązywaniu najpilniejszych problemów społecznych. Starają się być trybuną poglądów, nastrojów i opinii społecznych. We współczesnej Rosji, z powodu rosnącej tendencji do upaństwowienia wszystkich dziedzin życia społecznego, taka działalność organizacji pozarządowych wydaje się niemożliwa. Przeszkoda jest także brak wykwalifikowanych kadr oraz bierna postawa wobec zmian społecznych większości społeczeństwa rosyjskiego,

- ogólnie mówiąc, zarówno w Polsce, jak i w Rosji dopiero w ostatnim dziesięcioleciu zaczęto zwracać uwagę na rolę lokalnych instytucji kultury w procesie integracji miejscowych społeczności. W Rosji ośrodki lokalne często podejmują się pełnienia funkcji narzędzia wychowania patriotycznego, zwłaszcza młodzieży (stąd popierane ze środków Ministerstwa Kultury albo samorządu konkursy i festiwale o charakterze patriotycznym, poświęcone ważnym datom w rosyjskiej historii). W Polsce nacisk kładzie się bardziej na zachowanie narodowego dziedzictwa kulturowego, pielęgnowanie lokalnych tradycji; istnieje pojęcie „małej ojczyzny”, które dla większości Rosjan mogłoby być niezrozumiałe (w rozumieniu większości Rosjan wychowanych w kulturze rosyjskiej ojczyzną jest cały kraj),

- wprowadzając metody animacji kulturalnej w Rosji, warto wiedzieć, że największa popularnością na rosyjskiej prowincji cieszą się takie projekty, których organizatorzy wybierają zrozumiałe, uniwersalne, patriotyczne hasła. Do mieszkańców wiosek bardziej przemawia treść związana z historią Rosji i jej zwycięstwami, niż nawoływanie do budowy demokracji. Są oni także bardziej skłonni angażować się w imprezy na poziomie lokalnym, organizowane przez „swoich”, niż brać udział w oficjalnych przedsięwzięciach dużych instytucji państwowych. Udane okazują się także takie inicjatywy, które sprzyjaja wspólnemu spędzaniu wolnego czasu przez wielopokoleniową rodzinę,

- zarówno w Polsce, jak i w Rosji skuteczność instytucji kultury w dużym stopniu zależy od zaangażowania ich pracowników, szczególnie na poziomie lokalnym. Starania o przekształcenie ośrodków w centra życia kulturalnego i aktywności społecznej skutkują integracją społeczności lokalnej, co niekiedy ma większe znaczenie, niż zdobywanie przez te instytucje środków finansowych. 
Artykuły

\section{Bibliografia}

Bukraba-Rylska Izabella, 2000, Kultura w społeczności lokalnej-podmiotowość odzyskana?, Warszawa: Instytut Rozwoju Wsi i Rolnictwa Polskiej Akademii Nauk.

Dyczewski Leon, 1993, Animator kultury lokalnej, w: tegoż, Kultura polska w procesie przemian, Lublin: Wydawnictwo Towarzystwa Naukowego KUL.

Ewremow Siergiej, Kunin Evgenij, 1990, Perspektivnye modeli uczrezdenii kultury, w: Perspektivnye modeli uczrezdenii kultury, red. Siergiej Ewremow, Evgenij Kunin, Moskwa: Akademia Nauk RSFSR.

Gajewska Julia, 1992, Finansowanie kultury w gminie, w: Barometr kultury, red. Mirosława Grabowska, Warszawa: Instytut Kultury.

Gawda Witold, red., 1991, Nierówności w kulturze Polaków i Rosjan, Warszawa: Instytut Kultury. Grad Jan, Kaczmarek Urszula, 2005, Organizacja i upowszechnienie kultury w Polsce. Zmiana modelu, Poznań: Wydawnictwo Naukowe UAM.

Kisilewa Tatiana, Krasilnikow Jurij, 2004, Socjalno-kulturnaja deiatelnosti, Moskwa: Moskiewski Uniwersytet Kultury i Sztuki.

Koweshnikowa Ewgenia, 2008, Muzeianaia kommunikacia i miezdukulturnyi dialog, Kemerowo: Instytut Kultury i Sztuki.

Mołda Sławomir, Skrzypczak Bogdan, red., 2003, Ośrodek kultury i aktywności lokalnej. W poszukiwaniu modelu instytucji społecznościowej, Warszawa: Stowarzyszenie Centrum Wspierania Aktywności Lokalnej CAL.

Skrzypczak Bogdan, 2003, Dokąd zmierza dom kultury?, w: Ośrodek kultury i aktywności lokalnej w poszukiwaniu modelu instytucji społecznościowej, red. Bogdan Skrzypczak, Sławomir Mołda, Warszawa: Stowarzyszenie Centrum Wspierania Aktywności Lokalnej CAL. Tarnavskyi Viktor, 2007, Dzieci swoich czasów. Ruchy młodzieżowe w Rosji a zmiany kulturowe po upadku ZSRR, Warszawa: TRIO.

W Rossii otkryli park ptic, „Wiadomości Kaługi”, 22.07.2004, www.gnuman.ru/travel/voroby http://ogniwa-tratwa.pl/

http://www.amcult.ru/ 


\section{The place of cultural animation in the activity of Polish and Russian local institutions of culture after the fall of communism (selected examples)}

The main objective of this article is to explore and compare the role of cultural animation in the activity of local institutions of culture in Poland and Russia after the fall of communism. Among the significant issues are the strategy of local cultural institutions within the terms of the market economy, the system of values that they promote and the conditions of effective cooperation of these institutions with their audiences. One of the important questions is the institution's ability to meet the cultural needs of a local community and simultaneously create a 'civic conscience' in people. The author has explored the activity of selected local institutions of culture in Poland and in Russia.

\section{Key words:}

cultural animation, transformation, institutions of culture, local communities, integration

Słowa kluczowe:

animacja kultury, transformacja, instytucje kultury, społeczności lokalne, integracja 